\title{
The 5-HTP sip tryp: a timely word to the wise
}

\author{
This article was published in the following Dove Press journal: \\ ChronoPhysiology and Therapy \\ 24 May 2013 \\ Number of times this article has been viewed
}

\section{Priyoneel Basu \\ Muniyandi Singaravel}

Chronobiology Laboratory, Department of Zoology, Banaras Hindu University, Varanasi, India
Correspondence: Muniyandi Singaravel Chronobiology Laboratory,

Department of Zoology, Banaras Hindu University, Varanasi-221005, India $\mathrm{Tel}+915426701819$

Email m_singaravel@yahoo.com; priyoneel@gmail.com

\section{Dear editor}

Recently, an editorial in Nature Neuroscience pointed out the need for exercising caution in the use of over-the-counter drinks purporting to promote relaxation and containing, among other substances with chronobiotic activity, L-5-Hydroxytryptophan (5-HTP). ${ }^{1}$ This reality-check certainly raises an issue worth the attention of scientists who deal with, and laymen who dabble in, biological rhythms. Proprietary and patented formulations often project an image of safety, which is augmented by their over-thecounter availability as attractively packaged nutritional supplements. The allure of these bottled shots of bliss may seem undeniable to the general public. An online search of the words "5-HTP relaxation drink" returns $>7$ million websites. Websites promoting these drinks do carry limited warnings or disclaimers (in fine print). The actual concentration of constituents is sometimes not provided in the online information leaflets. Certain websites provide a Natural Standard Editorial Board blinded review, ${ }^{2,3}$ which summarizes known scientific literature (exhaustively) and mentions likely safe doses. In view of the rising popularity and wide availability of 5-HTP containing drinks, we feel that scientists and the general public alike would profit from an additional nugget of information regarding a previously unforeseen effect of 5-HTP consumption at an inappropriate time, as brought to light by recent literature in the area.

5-HTP crosses the blood-brain barrier upon systemic administration, bypasses the rate-limiting step in serotonin synthesis, elevates brain serotonin, ${ }^{4}$ and affects non-REM sleep ${ }^{5}$ in rodents, generally promoting wakefulness if administered at light onset, and promoting non-REM sleep with dark onset administration. In a recent study (March 2012), we investigated some of the effects 5-HTP had on the mammalian circadian system, using a nocturnal model. ${ }^{6}$ In nocturnal mice, 5-HTP causes phase advances during the mid-subjective day, phase delays during the mid-subjective night and, at certain other times, ambiguous or no apparent phase-shifting effects at all. In this paper, we had expressed concern regarding the potentially detrimental effects caused by temporally inappropriate administration of 5-HTP, especially in cases where the circadian system has been previously subjected to a stressor, for example jet lag, and this is a caveat not mentioned by many, or perhaps any, marketers of these products. Additionally, experiments conducted at our lab using nocturnal field mice ${ }^{7}$ indicate that 5-HTP administered in the late subjective night, when combined with light, may actually transiently increase locomotor activity, along with increasing light-induced phase shifts, through possibly arousal-dependent mechanisms most likely involving 
serotonergic potentiation ${ }^{8}$ of light-induced phase shifts. Therefore, even after taking into consideration the fact that potentiation responses are generally opposite in nocturnal and diurnal mammals, ${ }^{9}$ usage of 5-HTP-containing drinks at user-selected times, or without knowledge of previous history of circadian entrainment and disruption, can potentially lead to resetting of the biological rhythm in unwanted ways.

It is worth mentioning here that 5-HTP actually accelerates reentrainment to a 6-hour phase advanced lighting schedule (simulating shift work/jet lag), ${ }^{10}$ and thus might possibly be of therapeutic use in such a situation, only if administered at an appropriate time. In a certain clinical condition, a serotonergic phase advance of the circadian system might have some desirable effects (eg, in delayed sleep phase syndrome combined with social phobia). However, if the temporal response of the circadian system to an over-the-counter serotonergic agent such as 5-HTP is not considered, the dosage may be administered at a phase which could have non-beneficial or even harmful consequences, whereas a properly timed administration would cause a potentially beneficial phase adjustment. Thus, 5-HTP may prove to be a double-edged sword, with the consequences implied, if not wielded with more responsibility. The scientists working in the area must endeavor to disseminate awareness in the scientific community and the general populace in this regard.

\section{Disclosure}

The authors report no conflicts of interest in this communication.

\section{References}

1. Narsimhan K. Sip carefully. Nat Neurosci. 2012;15(4):497.

2. Dream Water [homepage on the Internet]. Natural standard report. http://www.drinkdreamwater.com/natural-standard. Accessed April 26, 2013.

3. Lanilai [homepage on the Internet]. Calming effect of LANILAI relaxation Drinks. https://lanilai.com/anti-stress-drink-benefits/stress-relief/. Accessed April 26, 2013.

4. Lynn-Bullock CP, Welshhans K, Pallas SL, Katz PS. The effect of oral 5-HTP administration on 5-HTP and 5-HT immunoreactivity in monoaminergic brain regions of rats. J Chem Neuroanat. 2004;27(2): 129-138.

5. Morrow JD, Vikraman S, Imeri L, Opp MR. Effects of serotonergic activation by 5 -Hydroxytryptophan on sleep and body temperature of $\mathrm{C} 57 \mathrm{~B} 1 / 6 \mathrm{~J}$ and interleukin-6-deficient mice are dose and time related. Sleep. 2008;31(1):21-33.

6. Basu P, Singaravel M, Haldar C. L-5-hydroxytryptophan resets the circadian locomotor activity rhythm of the nocturnal indian pygmy field mouse, Mus terricolor. Naturwissenschaften. 2012;99(3):233-239.

7. Basu P, Singaravel M. Potentiation of light-induced phase shifts by 5-Hydroxy-L-tryptophan in pygmy field mice: A preliminary report. Biol Rhythm Res. 2012. In press.

8. Bartoszewicz R, Chmielewska D, Domoń M, Barbacka-Surowiak G. Influence of short-term constant light on phase shift of mouse circadian locomotor activity rhythm induced by agonist and antagonist of serotonin. Biol Rhythm Res. 2010;41(4):279-288.

9. Cuesta M, Mendoza J, Clesse D, Pévet P, Challet C. Serotonergic activation potentiates light resetting of the main circadian clock and alters clock gene expression in a diurnal rodent. Exp Neurol. 2008; 210(2):501-513.

10. Basu P, Singaravel M. Acceleration of re-entrainment during a 6-h acute jet lag simulation by 5 -Hydroxy-L-tryptophan in pygmy field mice. Biol Rhythm Res. 2013. In press.
ChronoPhysiology and Therapy

\section{Publish your work in this journal}

ChronoPhysiology and Therapy is an international, peer-reviewed, open access journal focusing on research into the cyclic variations and rhythmicity in physiological processes in the body and the research and development and optimal timing of administration of therapeutic targets to achieve improved outcomes and quality of life for the patient. The

\section{Dovepress}

manuscript management system is completely online and includes a very quick and fair peer-review system. Visit http://www.dovepress.com/ testimonials.php to read real quotes from published authors. 